\title{
UPAYA PENINGKATAN KOMPETENSI PROFESI PUSTAKAWAN DALAM MENDUDUKI JABATAN FUNGSIONAL
}

Efforts to Improve Librarian Profession Competency in Populating Functional Positions

\author{
WAHIDA \\ Biro Organisasi Setda Provinsi Jambi \\ Jalan Jend. A. Yani No. 01 Telanaipura Jambi, 36124 \\ E-mail : wahidajbi@yahoo.co.id
}

Diterima: 05 November 2019; di revisi: 10 November 2019 Disetujui : 02 Desember 2019

https://doi.org/10.37250/newkiki.v3i2.45

\begin{abstract}
Abstrak
Kompetensi merupakan kemampuan dan keahlian yang dimiliki oleh tenaga kerja professional. Termasuk tenaga pustakawan yang diwajibkan memiliki kompetensi pendidikan dan keahlian di bidang kepustakawanan. Pustakawan dituntut untuk senantiasa meningkatkan kompetensi dan profesionalisme dalam melaksanakan tugas dan fungsinya. Penelitian ini bertujuan untuk mendiskripsikan upaya yang harus dilakukan dalam meningkatkan kompetensi profesi pustakawan dalam menduduki jabatan fungsional . Penelitian ini menggunakan studi literature. Studi literatur dalam penelitian ini adalah menggali informasi yang berkaitan dengan profesi dan kompetensi pustakawan dalam menduduki jabatan fungsional, sedangkan analisis data menggunakan metode analisis deskriptif. Dengan kompetensi yang memadai dan bekerja secara profesional, citra pustakawan dapat diubah menjadi lebih baik. Melalui peningkatan kompetensi dan profesionalisme, pustakawan dapat meningkatkan derajatnya sebagai tenaga profesional perpustakaan yang mampu berperan aktif dalam setiap aktivitasnya. Untuk mewujudkan hal tersebut, diperlukan beberapa strategi yang tepat, yaitu (1) meningkatkan kinerja secara berkesinambungan, (2) membangun komunikasi internal secara efektif, (3) menggagas ide-ide inovatif perpustakaan, (4) mengikuti program sertifikasi pustakawan, mengikuti diklat dan pelatihan layanan prima kepustakawanan, dan (5) melakukan pengembangan karier profesional.
\end{abstract}

Kata Kunci: Pustakawan, kompetensi, profesi. perpustakaan

\begin{abstract}
Competence is an ability and expertise possessed by a professional workforce. Including librarians who are required to have educational competence and expertise in the field of librarianship. Librarians are required to always improve their competence and professionalism in carrying out their duties and functions. This study aims to describe the efforts that must be made in increasing the professional competence of librarians in occupying functional positions. This research uses literature study. Literature study in this study is to explore information relating to the propesients and competencies of librarians in occupying functional positions, while data analysis uses descriptive analysis methods. With sufficient competence and working professionally, the librarian's image can be changed for the better. Through increasing competence and professionalism, librarians can increase their degrees as library professionals who are able to play an active role in each of their activities. To achieve this, several appropriate strategies are needed, namely (1) improving performance on an ongoing basis, (2) building internal communication effectively, (3) initiating innovative library ideas, (4) following the librarian certification program, following training and excellent librarian service training, and (5) professional career development.
\end{abstract}

Keywords: Librarian, competence, profession. Library

PENDAHULUAN

Kompetensi merupakan topik yang terus berkembang dalam profesi pustakawan karena kompetensi menjadi salah satu ciri profesi pustakawan. Kompetensi sebagai ciri pustakawan disebut dalam definisi pustakawan menurut Undang-undang No. 43 tahun 2007 tentang 
Perpustakaan, bahwa pustakawan adalah seorang yang memiliki kompetensi yang di peroleh melalui pendidikan dan/atau pelatihan kepustawanan serta mempunyai tugas dan tangung jawab untuk melaksanakan pengelolaan dan pelayanan perpustakaan (pasal 1 ayat 8 ).

Dalam pasal 3 Undang-undang No. 43 tahun 2007 tentang Perpustakaan yaitu perpustakaan sebagai salah satu pusat informasi bertugas memutakhirkan koleksi, menyediakan fasilitas, mengumpulkan, mengolah, dan menyajikan layanan informasi untuk dapat dimanfaatkan oleh pemustaka secara efektif dan efisien. Perkembangan dunia informasi membawa perubahan baru pada perpustakaan sebagai pengelola informasi tertua. Kondisi tersebut merupakan tantangan bagi kepustakawanan dalam memenuhi kewajibannya sebagai profesi yang berhubungan dengan tugas informasi. Perkembangan informasi dan teknologi komunikasi yang sangat pesat di era globalisasi ini membawa pengaruh besar di berbagai bidang kehidupan. Salah satunya adalah berpengaruh terhadap perpustakaan. Melimpahnya informasi dalam berbagai jenis maupun bentuk media, serta tersedianya perangkat yang mampu menunjang kegiatan yang sulit dilakukan di masa lalu, mengharuskan pustakawan yang dimaksud standar tenaga perpustakaan mencakup kualifikasi akademik, kompetensi, dan sertifikasi. Jelas sekali bahwa kompetensi pustakawan merupakan untuk melakukan perubahan terhadap perpustakaan yang peranan sebagai mediator informasi, fasilitator, dan pendamping pendidik.

Kepustakawanan adalah sebuah profesi. Akan tetapi, terkadang karena berkonsentrasi pada kegiatan teknis perpustakaan, lupa bahwa kepustakawanan sebenarnya adalah kegiatan antar manusia, yang berpusaran pada aktivitas menyimpan dan menata pustaka bagi keperluan para pencari informasi.

Dalam Undang-undang No. 43 Tahun 2007 tentang Perpustakaan disebutkan bahwa penyelenggaraan, pengelolaan, pengembangan perpustakaan mengacu pada standar nasional perpustakaan. Salah satu butir standar nasional perpustakaan adalah standar tenaga perpustakaan. Lebih lanjut dalam penjelasan Undang-undang tersebut dinyatakan bahwa unsur penting disamping kualifikasi akademik dan sertifikasi.

Berdasarkan pemaparan diatas, maka yang menjadi rumusan masalah dalam tulisan ini adalah bagaimana upaya dalam peningkatan kompetensi profesi 
pustakawan dalam menduduki jabatan fungsional.

\section{Metode Penelitian}

Penelitian ini termasuk jenis penelitian studi literatur dengan mencari referensi teori yang relevan. Studi literature bisa didapat dari berbagai sumber, jurnal, buku, dokumentasi, internet dan pustaka. Studi literatur dalam penelitian ini adalah menggali informasi yang berkaitan dengan propesi dan kometensi pustakawan dalam menduduki jabatan fungsional, sedangkan analisis data menggunakan metode analisis deskriptif yaitu sebagai prosedur pemecahan masalah yang diselidiki dengan menggambarkan keadaan subjek atau objek dalam penelitian dapat berupa orang, lembaga, masyarakat dan yang lainnya yang pada saat sekarang berdasarkan faktafakta yang tampak atau apa adanya. Menurut Sugiyono (2005: 21) menyatakan bahwa metode deskriptif adalah suatu metode yang digunakan untuk menggambarkan atau menganalisis suatu hasil penelitian tetapi tidak digunakan untuk membuat kesimpulan yang lebih luas.

\section{Tinjauan Literatur}

\section{Pustakawan}

Menurut pasal 1 Nomor 8 UU No. 43/2007 tentang Perpustakaan, pustakawan seorang yang memiliki kompetensi yang diperoleh melalui pendidikan dan/atau pelatihan kepustawanan serta mempunyai tugas dan tangung jawab untuk melaksanakan pengelolaan dan pelayanan perpustakaan. Online Dictiomary for Library and Information Science (OSLIS) mendefinisikan pustakawan sebagai orang yang terlatih secara professional yang bertangungjawab untuk menjaga perpustakaan dan isinya, termaksuk seleksi, proses dan organisasi material dan menyampaikan informasi, instruksi dan layanan peminjaman sesuai kebutuhan pengguna. Sedangkan menurut Zulkifar Zen (2007:1) pustakawan adalah profesi bagi yang bekerja di perpustakaan dan lembaga informasi lainya.

Di Indonesia dikenal istilah pustakawan fungsional yakni sebuah jabatan bagi ASN yang berprofesi sebagai pustakawan. Dalam Pasal 1 Ayat 1 Permenpan No. 9/2014 dijelaskan bahwa jabatan fungsional pustakawan adalah jabatan yang mempunyai ruang lingkup, tugas, tanggung jawab, wewenang dan hal untuk melaksanakan kegiatan kepustakawanan

\section{Kompetensi Pustakawan}

Munculnya Undang-undang Nomor 43 Tahun 2007 tentang Perpustakaan telah menumbuhkan harapan baru bagi tenaga 
perpustakaan dan pustakawan untuk meningkatkan kompetensinya. Standar kompetensi adalah rumusan tentang kemampuan yang harus dimiliki seseorang untuk melakukan suatu tugas atau pekerjaan yang didasari atas pengetahuan, keterampilan dan sikap kerja sesuai dengan kriteria unjuk kerja yang dipersyaratkan.

Mengintegrasikan definisi Marshal (2003) dan Nanan Khasanah (2008) Kompetensi adalah kemampuan untuk melaksanakan atau melakukan suatu pekerjaan atau tugas yang dilandasi atas keterampilan, dan pengetahuan serta didukung oleh sikap kerja yang dituntut oleh pekerjaan tersebut. Kompetensi dapat dibedakan menjadi dua tipe. Tipe kompetensi pertama yang disebut dengan "soft competency". Tipe kompetensi ini berkaitan erat dengan kemampuan untuk mengatur proses pekerjaan dan berinteraksi dengan orang lain. Yang termasuk dalam soft competency diantaranya adalah kemampuan manajerial , kemampuan memimpin (kepemimpinan), kemampuan komunikasi, dan kemampuan membangun hubungan dengan orang lain (Interpersonal relation). Sedangkan tipe kompetensi yang kedua yaitu "hard competency". Tipe kompetensi kedua tersebut berkaitan dengan kemampuan fungsional atau teknis suatu pekerjaan. Dengan kata lain, kompetensi ini berkaitan dengan seluk beluk teknis yang berkaitan dengan pekerjaan yang ditekuni. Contoh hard competency di bidang perpustakaan antara lain kemampuan untuk mengklasir, mengkatalog, mengindek, membuat abstrak, input data, melayani pemustaka, melakukan penelusuran informasi dan sebagainya.

Menurut Standar Kompetensi Kerja Nasional Indonesia (2012:12) kompetensi adalah kemampuan seseorang yang mencakup pengetahuan, keterampilan dan sikap kerja yang dapat menyelesaikan suatu pekerjaan atau tugas sesuai dengan standar kerja yang diterapkan. ODLIS mendefinisikan kompetensi sebagai kemampuan yang diharapkan dari seseorang yang ditugaskan untuk melaksanakan suatu pekerjaan yang spesifik atau telah menyelesaikan pendidikan atau pelatihan.

Menurut Standar Kompetensi Kerja Nasional Indonesia (SKKNI) bidang perpustakaan yang merupakan salah satu referensi standar pengelolaan perpustakaan yang dikeluarkan oleh Badan Nasional Sertifikasi Profesi (BNSP) bahwa standar kompetensi pustakawan sangat diperlukan. Paling tidak ada tiga pihak yang mempunyai kepentingan terhadap standar kompetensi pustakawan. Pertama adalah 
perpustakaan. Bagi perpustakaan, standar kompetensi pustakawan dapat dipergunakan sebagai pedoman untuk merekrut pustakawan dan mengembangkan program pelatihan agar tenaga perpustakaan mempunyai kompetensi atau meningkatkan kompetensinya. Kedua adalah lembaga penyelengara sertifikasi pustakawan. Bagi lembaga sertifikasi pustakawan, standar kompetensi pustakawan dapat dipergunakan sebagai acuan dalam melakukan penilaian kinerja pustakawan dan uji sertifikasi terhadap pustakawan. Sedangkan pihak ketiga adalah pustakawan. Bagi pustakawan standar kompetensi pustakawan dapat dipergunakan sebagai acuan untuk mengukur kemampuan diri untuk memegang jabatan pustakawan.

\section{Propesi}

Istilah profesi berasal dari kata pofess yang berarti 'pengakuan', kata profess atau profesi mula-mula digunakan pada abad pertengahan, yaitu di Eropa Barat, di Jerman, dan di berbagai negara Skandinavia dengan istilah Gilda, yakni perkumpulan orang yang memiliki keterampilan khusus, seperti tukang sepatu, tukang kayu, dan tukang pandai besi. Keterampilan khusus ini berkembang menjadi spesialisasi, yaitu orang yang mengkhususkan diri dalam sebuah pekerjaan khusus² (Sulistyo Basuki, 1993). Pengertian profesi merupakan pekerjaan dalam pengertian khusus dan dalam pengertian tertentu, tidak semua pekerjaan disebut profesi.

Profesi merupakan pernyataan atau janji terbuka, dan merupakan suatu jabatan atau pekerjaan tertentu yang dengan sendirinya menuntut keahlian pengetahuan dan keterampilan tertentu. Pekerjaan profesional berbeda dengan pekerjaan lainnya yang mempunyai fungsi sosial, yakni pengabdian kepada masyarakat. Kepustakawanan bisa dikategorikan sebagai suatu profesi dalam menjalankan tugasnya yang dilandasi dengan prinsipprinsip keprofesionalannya. Di Indonesia bidang pustakawan sudah memiliki kriteria sebagai bidang kerja yang profesional, dan jika dilihat dari berbagai indikator yang sudah dimiliki profesi kepustakawanan, misalnya IPI (lkatan Pustakawan Indonesia) sebagai organisasi profesi, program S1 (Strata), S2 (Magister) perpustakaan dan kode etik pustakawan pemerintah telah mengakui bahwa pekerjaan pustakawan merupakan kerja yang bersifat profesional, sebagaimana telah dikeluarkannya Surat Edaran bersama Menteri Pendidikan dan Kebudayaan dan Kepala BAKN No. 53649/MPK/1988, dan No. 15/SE/1988, tanggal 16 Juli 1988 dan 
diperbaharui dengan SK MENPAN No. 33 tahun 1988 tentang jabatan fungsional pustakawan dan angka kreditnya.

Profesi pustakkawan terus berkembang berbanding lurus dengan kemajuan masyarakat dan teknologi informasi, pustakawan adalah pekerjaan atau sebuah sebutan pekerjaan, terutama pekerjaan yang memerlukan pendidikan atau latihan. Profesi kepustakawanan adalah profesi yang mengemban pekerjaan diruang lingkup perpustakaan. Profesional adalah tenaga yang telah menjual teknik intelektual khusus dan isi intelektual khusus. Teknik dan isi inilah yang akan membedakan tenaga profesional dari tenaga terampil.

\section{Standar Kompetensi Kerja Nasional} Indonesia (SKKN) Bidang Perpustakaan

Standar Kompetensi Kerja Nasional Indonesia (SKKN) Bidang Perpustakaan merupakan salah satu referensi standar pengelolaan peerustakaan yang dikeluarkan oleh Badan Nasional Sertifikat Profesi (BNSP). Dalam SKKNI ini, pengetahuan, keterampilan dan sikap kerja diwujudkan dalam 4 (empat) kelompok unit kompetensi, yaitu kelompok kompetensi umum, kelompok kompetensi inti, kelompok kompetensi khusus dan kompetensi kunci.
Kompetensi umum adalah kompetensi dasar yang harus dimiliki oleh setiap pustakawan, diperlukan untuk melakukan tugas-tugas perpustakaan seperti : (1) Mengoperasikan komputer tingkat dasar, (2) Menyusun rencana kerja perpustakaan, (3) Membuat laporan kerja perpustakaan. Kompetensi umum ini melekat dalam kompetensi inti dan khusus.

Kompetensi inti adalah kompetensi fungsional yang harus dimiliki oleh setiap pustakawan dalam menjalankan tugastugas perpustakaan. Kompetensi inti mencakup unit-unit kompetensi yang dibutuhkan untuk mengerjakan tugas-tugas inti dan wajib dikuasai oleh pustakawan. Kompetensi inti meliputi: (1) Melakukan seleksi bahan perpustakaan, (2) Melakukan pengadaan bahan perpustakaan, Melakukan pengatalogan deskriptif, (4) Melakukan pengatalogan subyek, (5) Melakukan perawatan bahan perpustakaan, (6) Melakukan layanan sirkulasi, (7) Melakukan layanan referensi, Melakukan penelusuran informasi sederhana, (9) Melakukan promosi perpustakaan, (10) Melakukan kegiatan literasi informasi, (11) Memanfaatkan jaringan internet untuk layanan perpustakaan.

Kompetensi khusus merupakan kompetensi tingkat lanjut yang bersifat 
spesifik, meliputi: (1) Merancang tata ruang dan perabot perpustakaan, (2) Melakukan perbaikan bahan perpustakaan, (3) Membuat literatur sekunder, (4) Melakukan penelusuran informasi kompleks, (5) Melakukan kajian perpustakaan, (6) Membuat karya tulis Ilmiah.

Kompetensi kunci adalah sikap kerja yang harus dimiliki pustakawan untuk mencapai unjuk kerja yang dipersyaratkan dalam pelaksanaan setiap unit kompetensi (umum, inti dan khusus).

\section{PEMBAHASAN}

\section{Upaya Meningkatkan Kompetensi}

\section{Pustakawan}

Pustakawan dituntut untuk senantiasa meningkatkan kompetensi dan profesionalisme dalam melaksanakan tugas dan fungsinya. Hal tersebut dimaksudkan agar pustakawan dapat berkompetisi dan berkolaborasi dengan profesi informasi yang lain, khususnya untuk memajukan dunia kepustakawanan. Kompetensi dan profesionalisme menjadi hal terpenting bagi pustakawan di perpustakaan dalam menjaga dan meningkatkan eksistensi mereka di lingkungan pekerjaannya. Dengan kompetensi yang memadai dan bekerja secara profesional, citra pustakawan dapat diubah menjadi lebih baik karena selama ini masyarakat masih menganggap pustakawan hanya sebagai tenaga teknis dan administrasi perpustakaan. Melalui peningkatan kompetensi dan profesionalisme, pustakawan dapat meningkatkan derajatnya sebagai tenaga profesional perpustakaan yang mampu berperan aktif dalam setiap aktivitas.

Kegiatan yang berkaitan dengan pengembangan SDM pustakawan antaralain: mengukuti diklat atau pelatihan, sertifikasi kompetensi, melanjutkan pendidikan tinggi.

Beberapa kompetensi yang mutlak harus dimiliki seorang pustakawan di perpustakaan adalah :

1. Kompetensi dibidang teknologi informasi. Pada era perkembangan teknologi informasi dan komunikasi dewasa ini yang begitu pesat, menuntut seorang pustakawan untuk lebih berkonsentrasi pada bidang keahlian ini dengan menguasai berbagai perangkat lunak maupun perangkat keras. Sehingga dengan kondisi tersebut diharapkan seorang pustakawan di perpustakaan memiliki kompetensi di bidang teknologi informasi, baik dari aspek keahlian dan teknis maupun non teknis. 
2. Kompetensi pribadi. Dalam proses pembelajaran, pustakawan memegang peranan yang cukup penting tertutama dalam menyediakan berbagai sumber informasi yang dibutuhkan oleh pemustaka. Untuk dapat menjalankan tugas dan fungsinya, seorang pustakawan harus memiliki kompetensi pribadi. Kompetensi pribadi pustakawan meliputi kondisi internal pustakawan yang ditandai dengan adanya kemampuan dan integritas pribadi , misalnya

a. Berpikir dinamis, yaitu peka dan terbuka terhadap perubahan atau pembaharuan agar institusi dimana pustakawan berkarya dapat tetap eksis dan berkembang.

b. Berpikir alternatif, artinya seorang pustakawan dituntut untuk dapat memiliki berbagai alternatif pemecahan masalah dalam melaksanakan tugas dan fungsinya.

c. Bertindak kreatif dan inovatif, artinya seorang pustakawan dituntut untuk dapat memiliki kekayaan gagasan dan ide terutama yang berkaitan dengan pengambilan keputusan yang terkait dengan tugas kepustakawanannya. Dengan kreativitas pustakawan dapat menciptakan situasi bekerja yang menarik.

d. Bersikap adil, jujur dan objektif dalam melaksanakan tugas kepustakawanannya. Artinya seorang pustakawan dituntut untuk tidak memberikan perlakuan yang berbeda kepada seluruh pemustaka.

e. Berdisiplin dalam melaksanakan tugas. Disiplin muncul dari kebiasaan hidup melalui proses pembelajaran dan pelatihan yang teratur serta mencintai dan menghargai pekerjaannya.

f. Keuletan dan ketekunan bekerja tanpa mengenal lelah dan tanpa pamrih merupakan hal yang perlu dimiliki oleh seorang pustakawan. Pustakawan yang ulet memiliki mentalitas pejuang yang tidak mudah putus asa apabila menghadapi persoalan yang berat atau kegagalan. Keuletan dan ketekunan bekerja merupakan faktor pendorong keberhasilan.

g. Berusaha mencapai hasil kerja yang sebaik baiknya. Untuk mencapai hal tersebut diharapkan pustakawan selalu berusaha meningkatkan potensi diri, 
mencari metode baru agar produk yang dihasilkan mampu memberikan kepuasan kepada pimpinan tempat pustakawan bekerja

h. Simpatik, menarik, luwes, bijaksana, bersifat terbuka dan berwibawa. Sifat-sifat tersebut memerlukan kematangan kepribadian, kedewaaan sosial dan emosional, pengalaman hidup bermasyarakat. Pustakawan dengan sifat-sifat tersebut pasti akan disenangi oleh pemustaka dan pimpinan tempat intansi pustakawan bekerja sehingga terbangun hubungan emosional yang baik antara pustakawan dengan masyarakat pemakainya.

Burstyn (1986) sebagaimamana dikutip Sugiarto

mengemukakan bahwa seorang pustakawan harus memiliki keterampilan interpersonal atau interpersonal skill, yaitu suatu keterampilan berkomunikasi yang mencakup kelancaran dan ketepatan dalam berbahasa lisan. Bahasa nonverbal, baik yang digunakan untuk menyampaikan maupun menerima suatu informasi juga merupakan bagian dari keterampilan berkomunikasi.

Komponen keterampilan interpersonal meliputi hal-hal berikut: memberi dan menerima umpan balik, mendengarkan, assertiveness, memberi informasi, presentasi, resolusi konflik, negoisasi, dan partisipasi dalam suatu pertemuan,

3. Kompetensi profesional. Pustakawan sebagai jabatan fungsional memerlukan keahlian khusus karena sebagai suatu profesi, pustakawan harus memiliki syarat profesional.

\section{Peningkatan Profesi}

Profesionalisme

pustakawan mempunyai arti pelaksanaan kegiatan perpustakaan yang didasarkan pada keahlian dan rasa tanggungjawab sebagai pengelola perpustakaan. Keahlian menjadi faktor penentu dalam menghasilkan hasil kerja serta memecahkan masalah yang mungkin muncul. Sedangkan tanggungjawab merupakan proses kerja pustakawan yang tidak semata-mata bersifat rutinitas, tetapi senantiasa dibarengi dengan upaya kegiatan yang bermutu melalui prosedur kerja yang benar. Ciri-ciri profesionalisme seorang 
pustakawan dapat dilihat berdasarkan karakteristik-karakteristik sebagai berikut;

1. Memiliki ilmu pengetahuan, keterampilan, kecakapan dan keahlian yang mumpuni dalam bidangnya

2. Memiliki tingkat kemandirian yang tinggi

3. Memiliki kemampuan untuk berkolaborasi dan bekerja sama

4. Senantiasa berorientasi pada jasa dan menjunjung tinggi kode etik pustakawan

5. Senantiasa melihat ke depan atau berorientasi pada masa depan .

Profesionalisme dalam setiap pekerjaan pustakawan saat ini mutlak dibutuhkan, dengan memiliki cara kerja pelayanan dengan berprinsip pada people based service (berbasis pengguna) dan service excellence (layanan prima) yang hasilnya diharapkan dapat memenuhi kepuasan penggunanya. Dampak positifnya adalah peran pustakawan semakin diapresiasi oleh banyak kalangan dan citra lembaganya (perpustakaan) akan menjadi naik.

\section{Upaya dalam meningkatkan pengembangan profesi pustakawan.}

Ada beberapa cara untuk meningkatkan pengembangan profesi pustakawan, diantaranya :
1. Mengikuti seminar yang berkaitan dengan kegiatan perpustakaan, dokumentasi dan informasi. Kegiatan seminar merupakan kegiatan yang didalamnya melibatkan sumber informasi dan penerima informasi. Dalam kegiatan seminar yang diikuti oleh pustakawan, nantinya akan memberikan wawasan yang luas mengenai perkembangan perpustakaan yang terjadi saat ini, sehingga nantinya informasi yang didapat pada seminar berguna bagi pustakawan dalam menjalankan kegiatannya di perpustakaan.

2. Mengikuti pelatihan yang berkaitan dengan kegiatan perpustakaan, dokumentasi dan informasi. Pustakawan diharapkan mengikuti pelatihan yang berkaitan dengan Perpustakaan untuk meningkatkan kompetensinya sehingga berdampak kepada pengembangan profesi yang semakin berkualitas. Dalam perkembangan teknologi saat ini, kegiatan pelatihan lebih banyak menitikberatkan kepada pemanfaatan sistem untuk di perpustakaan, seperti SLIMS, INLISLite.

Dengan adanya pelatihan yang diikuti oleh pustakawan dapat memberikan kontribusi positif terhadap kemajuan 
perpustakaan dan peningkatan profesi pustakawan.

3. Melanjutkan pendidikan formal pendidikan formal menjadi salah satu alternatif yang penting dalam pengembangan profesi pustakawan. Melalui pendidikan formal, pustakawan lebih banyak memperoleh ilmu yang bersifat ilmiah dan dapat memperoleh angka kredit yang lebih besar setelah menyelesaikan pendidikan formal. Selain itu, pustakawan yang mengikuti pendidikan formal dapat semakin mengembangkan wawasan melalui literatur-literatur yang diperoleh saat mengikuti pendidikan formal.

4. Berpartisipasi dalam forum Ikatan Pustakawan Indonesia (IPI) Ikatan Pustakawan Indonesia sebagai wadah bagi seluruh pustakawan untuk melakukan pertukaran informasi berkaitan dengan perkembangan yang terjadi di perpustakaan. Melalui forum Ikatan Pustakawan Indonesia (IPI) diharapkan pustakawan menjadi lebih aktif dan saling berkontribusi untuk kemajuan perpustakaan dan pengembangan profesi pustakawan.

Selain itu, ada beberapa hal yang perlu diperhatikan untuk meningkatkan profesionalisme pustakawan (Istiani, 2014 : 76-81), antara lain :

1. Bekerja berdasarkan ilmu pustakawan harus menguasai pengetahuan dasar mengenai ilmu perpustakaan dimulai dari kegiatan menghimpun bahan pustaka, mengolah, menyebarluaskan dan melestarikan informasi. Penguasaan pengetahuan tersebut dapat diperoleh melalui pendidikan formal atau dengan mengikuti diklat. Selain itu pustakawan harus mampu mengikuti dengan perkembangan kebutuhan pengguna perpustakaan dan mampu menyikapi berbagai inovasi sehingga perpustakaan akan senantiasa sebagai pilihan tempat yang tepat untuk melakukan berbagai bentuk pembelajaran.

2. Kemampuan intrapersonal. Kemampuan intrapersonal adalah kemampuan seseorang untuk memahami dirinya sendiri. Karakteristik seseorang yang memiliki kemampuan intrapersonal mencakup beberapa hal sebagai berikut : a) Memiliki tanggung jawab b) Mampu mengenali perasaannya dan mengarahkan emosi pribadinya c) Mempunyai 
kepercayaan diri d) Berani mengambil keputusan e) Mampu memotivasi diri sendiri f) Mampu mengintrospeksi diri dan memperbaiki kekurangannya

\section{Hambatan yang di dihadapi dalam peningkatan komptensi profesi pustakawan}

Hambatan yang dihadapi oleh pustakawan dalam upaya peningkatan kompetensi profesi pustakawan dalam menduduki jabatan fungsional antara lain :

1. Keterbatasan dana dalam kegiatan diperpustakaan

2. Tingkat pendidikan yang beraneka ragam, berpengaruh terhadap kegiatan pustakawan yang tanpak nyata dalam penerbitan, kegiatan ilmiah, kongres. Hal inipun dirasakan oleh banyak penulis kepustakawanan yang mengalami kesulitan bilamana harus berbicara di depan pustakawan.

3. Kelemahan perekrutan yaitu siapa saja yang berpendidikan D2 bidang apa saja ditambah dengan pendidikan kepustakawanan (CPTA) selama 3 bulan dapat diangkat menjadi pustakawan fungsional, secara tidak langsung praktek semacam ini akan berarti bunuh diri karena begitu mudah untuk menjadi pustakawan, belum lagi alih jalur S1 nonpustakawan
4. Ketidaksiapan menghadapi digitalisasi perpustakaan, banyak pustakawan tidak siap menghadapinya pekerjaan yang sulit dan membutuhkan pemikiran dan tenaga yang kuat setiap waktu, sedangkan hak pustakawan baik angka kredit dan tunjangan fungsional pustakawan masih relatif kecil.

\section{Kesimpulan}

1. Untuk dapat mewujudkan kinerja unggulan, seorang pustakawan pada perpustakaan dituntut memiliki kompetensi yang sesuai dengan tuntutan jabatannya yang mencakup kompetensi teknologi informasi, pribadi, sosial dan profesional.

2. Kompetensi dan profesionalisme menjadi hal terpenting bagi pustakawan di perpustakaan dalam menjaga dan meningkatkan eksistensi mereka di lingkungan pekerjaannya. Dengan kompetensi yang memadai dan bekerja secara professional.

3. Dalam rangka mendukung terwujudnya perpustakaan yang handal tersebut, maka diperlukan pustakawan yang memiliki kompetensi yang tinggi baik kompetensi profesional dan kompetensi personal/individu dengan mengadakan pelatihan dan penulisan 
baik penulisan karya ilmiah, penulisan laporan atau penulisan Term of Reference (TOR)

4. Kompetensi inti tergambar dari upaya mengikuti diklat dan pelatihan teknis layanan prima yang merupakan upaya untuk mengasah kecakapan pustakawan untuk mengerjakan kegiatan yang menjadi kompetensi inti dibidang layanan sepertyi malakukan layanan sirkulasi dan layanan referansi.

\section{Daftar Pustaka}

Abeng, Tanri.2007. Profesi Manajemen : Kristalisasi Teori dan Praktik Pemebelajaran Manajemen Korporasi, Lembaga Nirlaba, dan Pemerintahan. Jakarta : Gramedia Pustaka Utama

Hartono. (2015). Menggali Potensi Pustakawan Menuju Manajemen Perpustakaan Profesional. Buletin Perpustakaan Bung Karno. Th. VII/Vol. I/2015. 26-28.

Istiana, Purwani. 2014. Layanan Perpustakaan. Yogyakarta: Ombak

Panggabean, Mutiara S. 2004. Manajemen Sumber Daya Manusia. Bogor : Ghalia Indonesia
Kamila Kinanti. (2019). Upaya Peningkatan Kompetensi Pustakawan Fungsional : Studi Kasus Pada Perpustakaan Universitas X. Media Pustakawan Vol. 26 No. 2 Tahun 2019

Perpustakaan Nasional RI. (2012). Keputusan Menteri Tenaga Kerja dan Transmigrasi Republik Indonesia Nomor 83 Tahun 2012 tentang Penetapan Rancangan Standar Kompetensi Kerja Nasional Indonesia Sektor Jasa Kemasyarakatan, Sosial Budaya, Hiburan, dan Perorangan Lainnya Bidang Perpustakaan menjadi Standar Kompetensi Kerja Nasional Indonesia. Jakarta: Perpustakaan Nasional RI.

Sulistyo Basuki. 2001. Kode Etik dan Organisasi Profesi, Jakarta: PB IPI

http://www.abc-clio.com/ODLIS/odlis_c.as px

Undang-undang Republik Indonesia Nomor 43 Tahun 2007 tentang Perpustakaan

http://www.scribd.com/doc/132613742/Ma kalah-Profesi-Pustakawan\#scribd

http://www.kompasiana.com/legendakamp us/hegemoni-kemajuan-masyarakat -perkembangan-iptek-pada-perpus takaan_562df250 349773dd077ee6 84 